\title{
Inhibition of breast cancer cell proliferation in repeated and non-repeated treatment with zoledronic acid
}

Toni Ibrahim ${ }^{1 *}$, Laura Mercatali ${ }^{1+}$, Emanuele Sacanna ${ }^{1}$, Anna Tesei ${ }^{2}$, Silvia Carloni ${ }^{2}$, Paola Ulivi ${ }^{2}$, Chiara Liverani ${ }^{1}$, Francesco Fabbri ${ }^{2}$, Michele Zanoni ${ }^{1}$, Wainer Zoli ${ }^{2}$ and Dino Amadori ${ }^{1}$

\begin{abstract}
Background: Zoledronic acid is used to treat bone metastases and has been shown to reduce skeletal-related events and exert antitumor activity. The present in vitro study investigates the mechanism of action of Zoledronic Acid on breast cancer cell lines with different hormonal and HER2 patterns. Furthermore, we investigated the efficacy of repeated versus non-repeated treatments.

Methods: The study was performed on 4 breast cancer cell lines (BRC-230, SkBr3, MCF-7 and MDA-MB-231). Non-repeated treatment (single exposure of 168 hrs' duration) with zoledronic acid was compared with repeated treatment (separate exposures, each of 48 hrs' duration, for a total of 168 hrs) at different dosages. A dose-response profile was generated using sulforhodamine B assay. Apoptosis was evaluated by TUNEL assay and biomolecular characteristics were analyzed by western blot.

Results: Zoledronic acid produced a dose-dependent inhibition of proliferation in all cell lines. Anti-proliferative activity was enhanced with the repeated treatment, proving to be statistically significant in the triple-negative lines. In these lines repeated treatment showed a cytocidal effect, with apoptotic cell death caused by caspase 3, 8 and 9 activation and decreased RAS and PMAPK expression. Apoptosis was not observed in estrogen receptor-positive line: p21 overexpression suggested a slowing down of cell cycle. A decrease in RAS and pMAPK expression was seen in HER2-overexpressing line after treatment.

Conclusions: The study suggests that zoledronic acid has an antitumor activity in breast cancer cell lines. Its mechanism of action involves the decrease of RAS and RHO, as in osteoclasts. Repeated treatment enhances antitumor activity compared to non-repeated treatment. Repeated treatment has a killing effect on triple-negative lines due to apoptosis activation. Further research is warranted especially in the treatment of triple-negative breast cancer.
\end{abstract}

Keywords: Bone metastasis, Breast cancer, Cell lines, Zoledronic acid

\section{Background}

Breast cancer is the most commonly diagnosed cancer in women in developed countries and over $50 \%$ of patients have bone involvement at relapse [1-4]. Bone metastasis is a major epidemiological and clinical problem in women with breast cancer, causing pain and other serious complications such as pathologic fracture,

\footnotetext{
* Correspondence: t.ibrahim@irst.emr.it

'Equal contributors

'Osteoncology Center, IRCCS Istituto Scientifico Romagnolo per lo Studio e la Cura dei Tumori (IRST), via P. Maroncelli 40, 47014, Meldola, FC, Italy
} Full list of author information is available at the end of the article spinal cord compression and hypercalcemia with poor quality of life and prognosis [5,6].

The skeleton is characterized by a dynamic balance between osteoclast (induced bone resorption) and osteoblast (stimulated bone formation) bone remodeling, which maintains physiological bone turnover. The diffusion of tumor cells in bone tissue breaks this process causing the disruption of bone integrity and serious skeletal complications [7-9]. Bone metastases from breast cancer are most often lytic, so that bone homeostasis is shifted toward bone resorption by osteoclasts.

\section{Biomed Central}


Bisphosphonates are potent antiresorptive drugs in widespread use that are well suited to the treatment of metabolic bone disease. These drugs bind avidly to hydroxyapatite crystals at sites of active bone metabolism, achieving therapeutic concentrations. Bisphosphonates are released during bone resorption and are internalized by osteoclasts, leading to inhibition of bone resorption itself and induction of osteoclast apoptosis [10].

The use of drug treatments has a positive impact on the quality of life, inducing both a reduction of skeletal related events (SRE) and death risk in patients with bone metastases from breast cancer [11-13]. In particular, Zoledronic acid (Zol) is a potent third-generation nitrogen-containing bisphosphonate, and, in recent years, it has had widespread clinical use in patients with breast cancer [14]. Furthermore, many preclinical studies have demonstrated that Zol has both direct and indirect tumor activity, reducing proliferation and viability of tumor cell lines in vitro [15]. The direct action occurs in a dose and time dependent manner to inhibit proliferation and induce apoptosis in breast cancer cell lines [16]. The indirect action depends on the modification of bone microenvironment that is less hospitable for cancer cells' growth. Furthermore, Zol is known to inhibit tumor cell adhesion and invasion $[17,18]$ and its potential antiangiogenic activity has recently been discovered $[19,20]$. In animal models, a reduction in skeletal tumor burden and slower progression of bone lesions was observed after Zol treatment [21,22]. Recent clinical data in the adjuvant setting of breast cancer has also shown that Zol also increases disease-free survival $[23,24]$.

However, one of the most important limitations of Zol which makes its direct anticancer effect difficult to demonstrate in vivo is its pharmacokinetics profile. After a 4-mg infusion the drug remains in the plasma circulation for 1-2 hours before localization to the bone, with a plasmatic peak of $1 \mu \mathrm{M}$. Studies on rats and dogs have shown that Zol levels rapidly decrease in plasma and non calcified tissue, whereas higher levels persist in bone and slowly diminish, with a half-life of about 240 days. Such results would seem to indicate that a part of $\mathrm{Zol}$ is reversibly taken up by the skeleton and that the disposition in blood and non calcified tissue is controlled by extensive uptake into and slow release from bone. The anticancer activity of this drug could be improved by increasing the availability of the drug in tissue outside the bone and by encapsulating it in liposome vehicles to lengthen its plasma half life. Other strategies could be to change the treatment schedule to low-dose protracted administration or to use synergistic combinations of drugs $[25,26]$.

Several Zol dosing schedules have been proposed for the treatment of osteoporosis and bone metastases
$[27,28]$. However, these schedules need to be optimized to maximize its antitumor effects [29,30]. The metronomic approach has already been studied, and, in particular, daily or repeated therapies with bisphosphonates have been reported to inhibit skeletal tumor growth in mouse models [21]. In cancer patients with bone metastases, repeated intermittent low-dose therapy with Zol has been shown to induce a decrease in VEGF levels in cancer patients.

The aim of this study is to compare the cytotoxic activity of repeated and non-repeated Zol treatment in 4 breast cancer cell lines that differ in their hormone receptors' and HER2 status. We also investigated the molecular pathways involved in the antitumor activity of Zol.

\section{Materials and methods Cell culture}

The study was performed on four breast cancer cell lines, MCF-7, SKBr3, MDA-MB-231, obtained from the American Type Culture Collection (Rockville, MD), and BRC-230, established in our laboratory [31]. Hormone receptor and HER2 status are listed in Figure 1. The cell lines were maintained as a monolayer at $37^{\circ} \mathrm{C}$ and subcultured weekly. Culture medium was composed of 45\% HAM F12 and 45\% DMEM supplemented with 10\% fetal calf serum, $1 \%$ insulin and $1 \%$ glutamine (Mascia Brunelli s.p.a., Milan, Italy). Cells were treated with Zol 24 hrs after seeding. Cells in the exponential growth phase were used for all experiments.

\section{Drugs}

Zoledronic acid $\left(\right.$ Zometa $\left.^{\circledR}\right)$ (Zol), kindly provided by Novartis (Milan, Italy), was solubilized and stored at a concentration of $50 \mathrm{mM}$ in sterile water at $-20^{\circ} \mathrm{C}$ and diluted in medium before use. Cells were exposed to $12.5,25$ and $50 \mu \mathrm{M}$ of Zol in chemosensitivity assay, and to $50 \mu \mathrm{M}$ of Zol for apoptosis and western blot analysis.

\section{Chemosensitivity assay}

Sulforhodamine B (SRB) assay was used according to the method of Skehan et al. [32]. Briefly, cells were trypsinized, counted and plated at a density of 3,000 cells/well in 96-well flat-bottomed microtiter plates $(200 \mu \mathrm{l}$ of cell suspension/well). In the chemosensitivity assay, experiments were run in octuplicate, and each experiment was repeated three times [33]. The optical density (OD) of cells was determined at a wavelength of $540 \mathrm{~nm}$ by a colorimetric plate reader. Growth inhibition and cytocidal effect of drugs were calculated according to the formula reported by Monks et al. [34]: [(OD treated - $\left.O D_{\text {zero }}\right)$ / $\left.\left(\mathrm{OD}_{\text {control }}-\mathrm{OD}_{\text {zero }}\right)\right] \times 100 \%$, when $\mathrm{OD}_{\text {treated }}$ is $\geq \mathrm{OD}_{\text {zero }}$. If $\mathrm{OD}_{\text {treated }}$ is above $\mathrm{OD}_{\text {zero }}$, treatment has induced a cytostatic effect, whereas if $\mathrm{OD}_{\text {treated }}$ is below $\mathrm{OD}_{\text {zero }}$, cell 


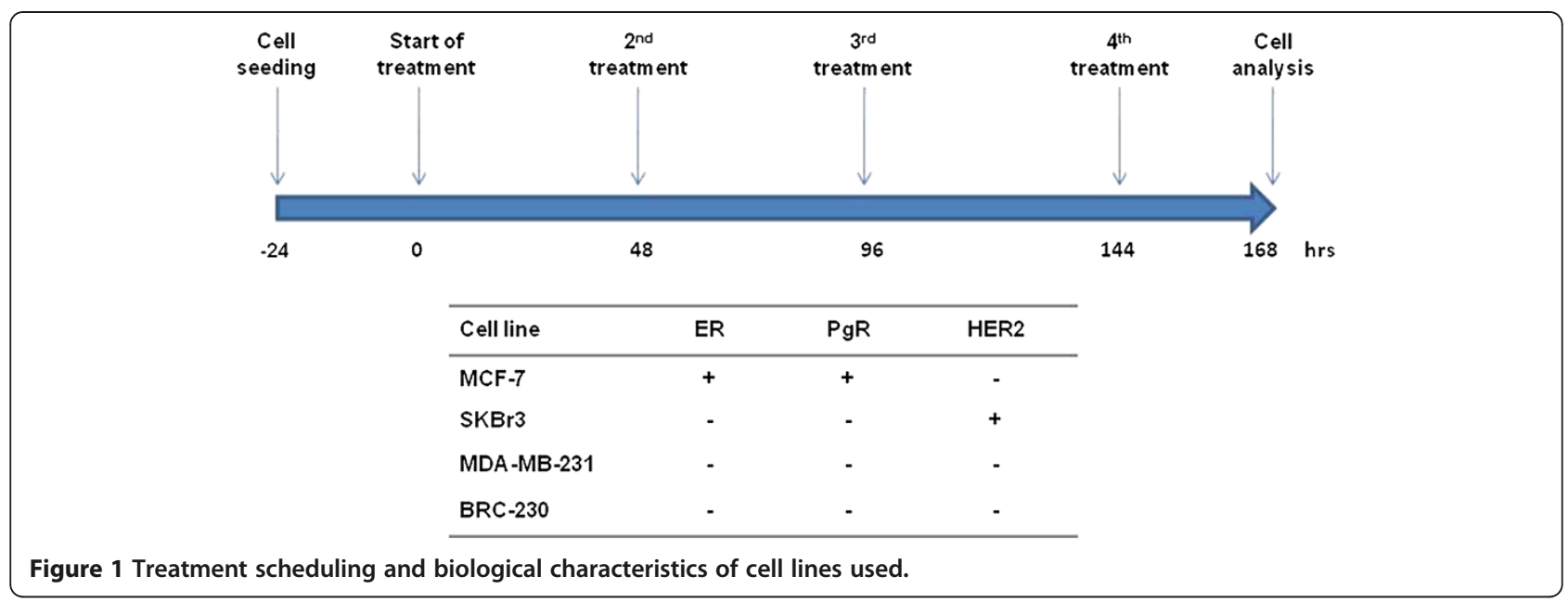

killing has occurred. The $\mathrm{OD}_{\text {zero }}$ depicts the cell number at the moment of drug addition, the $\mathrm{OD}_{\text {control }}$ reflects the cell number in untreated wells and the $\mathrm{OD}_{\text {treated }}$ reflects the cell number in treated wells on the day of the assay.

\section{Single drug exposure}

In the chemosensitivity assay, cells were exposed to repeated (RS) and non-repeated schedules (NRS). In NRS experiments, cells were exposed for 168 hrs, while in the RS experiments, cells were exposed every $48 \mathrm{hrs}$ to the same Zol concentration (Figure 1). All experiments were performed in triplicate and results were reported as the mean $50 \%$ inhibitory concentrations (IC50) of cell growth.

Treatment of cells for apoptosis evaluation, western blot and pull-down assay

Cells were plated at a density of $10^{6}$ cells in a flask $\left(75 \mathrm{~cm}^{2}\right)$ and were treated $24 \mathrm{hrs}$ after seeding with $50 \mu \mathrm{M}$ of Zol according to the two schedules described above. For apoptosis analysis, cells were detached from the flasks by trypsin at the end of treatment, washed twice with PBS and stained according to the different methods specified below. For western-blot analysis, cells were detached from the flasks and were then lysed by shaking for 5 minutes in B-PER Mammalian Protein Extraction Reagent (Pierce, Rockford, IL). For pulldown analysis, post-treatment cells were stimulated by EGF $100 \mathrm{ng} / \mathrm{ml}$ for 10 minutes at $37^{\circ} \mathrm{C}$ (Miltenyi, Bologna Italy ) to evaluate Ras activity, and by Rho activator 1 (Cytoskeleton, Denver, CO) $1 \mathrm{U} / \mathrm{ml}$ for $30 \mathrm{~min}$ at $37^{\circ} \mathrm{C}$ to assess Rho activity. Cells were then washed once with PBS, lysed by cell lysis buffer (Cytoskeleton) and detached using a scraper. Protein concentration was assessed using BCA Protein Assay kit (Pierce).

\section{Wound scratch}

Wound scratch assay was used to determine the migration of the four cell lines after Zol treatment (after $168 \mathrm{hrs})$. Cells were grown in flasks and the two treatments were performed. Twenty-four hours before stopping, a uniform cell-free area was created by scratching a confluent monolayer with a scraper. Wound closure was observed at the end of the experiments to determine cell line migration [35].

\section{Western blot}

An equal quantity of proteins was denatured and separated on Criterion-HCL gel 12.5\% Tris (Bio-Rad, Hemel Hempstead, UK) and electroblotted onto Immobilon-P Transfer Membrane (Millipore). The membrane was stained with Ponceau S (Sigma Aldrich, Milan, Italy) to verify equal amounts of sample loading and then incubated for $2 \mathrm{hrs}$ at room temperature with T-PBS 5\% non fat dry milk (Bio-Rad). The membrane was probed overnight at $4^{\circ} \mathrm{C}$ with the specific primary antibody, after which horseradish peroxidise-conjugated secondary antibody diluted 1:5,000 (Santa Cruz Biotechnology Inc, Santa Cruz, CA) was added. Bound antibodies were detected by Immun-Star Western C kit (Bio-Rad), using Chemidoc XRS Molecular Imager (Bio-Rad). The following primary antibodies were used: anti-p21 (monoclonal, 1:100) (BioOptica, Milan, Italy), anti-caspase 3 (polyclonal, 1:500), anti-caspase 9 (polyclonal, dilution 1:500), anti-bax (polyclonal, 1:1000), anti-pMAPK (polyclonal, 1:1000) (Cell Signalling Technology, Inc., Beverly, MA), anti-caspase 8 (monoclonal, 1:500) (Alexis Biochemicals, San Diego, CA), anti-RAS (polyclonal, 1:1000) (Stressgen, Exeter,UK), anti-Bcl-2 (monoclonal, 1:100) (Dako Corporation, Glostrup, Denmark), anti MCL-1 (monoclonal 1:100) (BD Pharmingen, San Jose, CA), anti rap1 (monoclonal 1:1000) (Abcam, Cambridge, UK) and anti- 
actin (polyclonal, 1:5000) (Sigma Aldrich), anti p-27 (monoclonal 1:2500) (BD Pharmingen, San Jose) and antiMAPK (polyclonal 1:1000) (Cell Signaling Technology).

\section{Ras and Rho activity evaluation}

The Ras/Rho Activation Assay Biochem kit (Cytoskeleton) was used according to the manufacturer's instructions. Briefly, we performed a pull- down analysis of the RAF-RBD/GTP-Ras complex and GTP-RHO RhotekinRBD [36,37]. The amount of activated Ras was then determined by quantitative western blot using a Ras and Rho pan specific antibody. Band density was evaluated by Quantity one software.

\section{Apoptosis}

For TUNEL assay, at the end of treatment cells were fixed in 1\% paraformaldehyde in PBS on ice for $15 \mathrm{~min}$ utes, suspended in ice cold ethanol (70\%) and stored overnight at $-20^{\circ} \mathrm{C}$. Cells were then washed twice in PBS and resuspended in PBS containing 0.1\%

Triton X-100 for 5 minutes at $4^{\circ} \mathrm{C}$. Thereafter, samples were incubated in $50 \mu \mathrm{l}$ of solution containing $\mathrm{TdT}$ and FITC-conjugated dUTP deoxynucleotides 1:1 (Roche Diagnostics GmbH, Mannheim, Germany) in a humidified atmosphere for 90 minutes at $37^{\circ} \mathrm{C}$ in the dark, washed in PBS, counterstained with propidium iodide $(2.5 \mu \mathrm{g} / \mathrm{ml}, \mathrm{MP}$ Biomedicals, Verona, Italy) and RNAse (10 Kunits/ml, Sigma Aldrich) for 30 minutes at $4^{\circ} \mathrm{C}$ in the dark and analyzed by flow cytometry.

Flow cytometric analysis was performed using a FACSCanto flow cytometer (Becton Dickinson, San Diego, CA). Data acquisition and analysis were performed using FACSDiva software (Becton Dickinson). Samples were run in triplicate and 10,000 events were collected for each replica. Data were the average of three experiments, with errors under $5 \%$.

\section{Cell cycle}

After Zol treatment and the different washouts (168 hrs), cells were fixed in ethanol (70\%), stained in a solution containing propidium iodide $(10 \mathrm{mg} / \mathrm{ml}, \mathrm{MP}$ Biomedicals, Verona, Italy), RNAse (10 kunits/ml, Sigma Aldrich) and NP40 (0.01\%, Sigma Aldrich) overnight at $4^{\circ} \mathrm{C}$ in the dark, and analyzed by flow cytometry. Data were expressed as fractions of cells in the different cell cycle phases. A pulse-chase experiment was performed on MDA-MB-231 treated with RS to evaluate S Phase. MDA-MB-231 was used because it was the most sensitive cell line to Zol. Samples were taken at baseline, after 72 and 168 hrs' treatment, and after a 48-hr washout.

\section{Bi-parametric BrdU-DNA content determination}

BrdU (20 mM, Sigma Aldrich) was added to cell medium 15 minutes before the start of scheduled treatment. Cells were incubated using the previously reported drug concentrations or in control medium. At the end of each exposure time, cells were fixed in icecold ethanol $(70 \%)$, stored overnight at $-20^{\circ} \mathrm{C}$, washed twice in PBS and incubated in $\mathrm{HCl} 2 \mathrm{~N}$ for $25 \mathrm{~min}$ at room temperature. Samples were then washed with $4 \mathrm{ml}$ of Na2B4O7 (0.1 M, pH8.5, Sigma Aldrich, Milan, Italy), incubated for $15 \mathrm{~min}$ at room temperature in PBS containing 0.5\% Tween 20 (Biorad) and BSA 1\% (Sigma Aldrich) and incubated with an anti-BrdU mouse antibody (NeoMarkers) (1/50 dilution in 0.5\% Tween 20 and BSA $1 \%$ ) for $1 \mathrm{hr}$ at room temperature in the dark. Cells were washed in PBS and incubated with a FITCconjugated anti-mouse immunoglobulin antibody (Dako Cytomation) (1/50 dilution in 0.5\% Tween 20 and BSA $1 \%$ ) for $1 \mathrm{~h}$ at room temperature in the dark. Before cytofluorimetric analysis, samples were washed with PBS and stained with propidium iodide $5 \mathrm{mg} / \mathrm{ml}$ (MP Biomedicals) and RNAse (MP Biomedicals) $1 \mathrm{mg} / \mathrm{ml}$ in PBS overnight at $4^{\circ} \mathrm{C}$ in the dark.

\section{Statistical analysis}

Differences between dose response, apoptosis and schedules of treatments were determined using the Student's $t$ test for unpaired observations. Statistical analyses were performed using the Statistical Package for Social Science (SPSS, version 17.0) and statistical significance was defined as $p<0.05$. All $p$ values were two-sided.

\section{Results}

\section{Cytotoxic activity}

Treatment cytotoxicity was assessed at scalar drug concentrations and IC50 value was calculated (Figure 2). The values of IC50 for RS were lower than those for NRS in all cell lines tested.

\section{Triple negative cell lines}

The NRS treatment induced, in MDA-MB-231 cells, a IC50 mean value of $29 \mu \mathrm{M}$ compared to $23 \mu \mathrm{M}$ for RS, with a decrease of $26 \%$ compared to standard treatment, $(p=0.042)$ (Figure 2). BRC-230 cells were more sensitive to Zol for both schedules, and more specifically, the IC50 decrease was $14 \%$ greater with RS compared to NRS ( $p=0.003)$. Moreover, a cytocidal effect was observed with RS, inducing a LC50 of $49 \mu \mathrm{M}$ and $40 \mu \mathrm{M}$ in MDA-MB-231 and BRC-230, respectively.

\section{MCF-7 and SkBr3 cell lines}

NRS treatment induced IC50 values of $23.6 \mu \mathrm{M}$ and $25.2 \mu \mathrm{M}$ in MCF-7 and SKBr3, respectively, while the RS schedule resulted in IC50 values of $29.0 \mu \mathrm{M}$ (MCF-7) and 26.4 $\mu \mathrm{M}$ (SKBr3) (Figure 2). Neither of the two treatment schedules induced a cytocidal effect. As the highest concentration produced the strongest effect in 

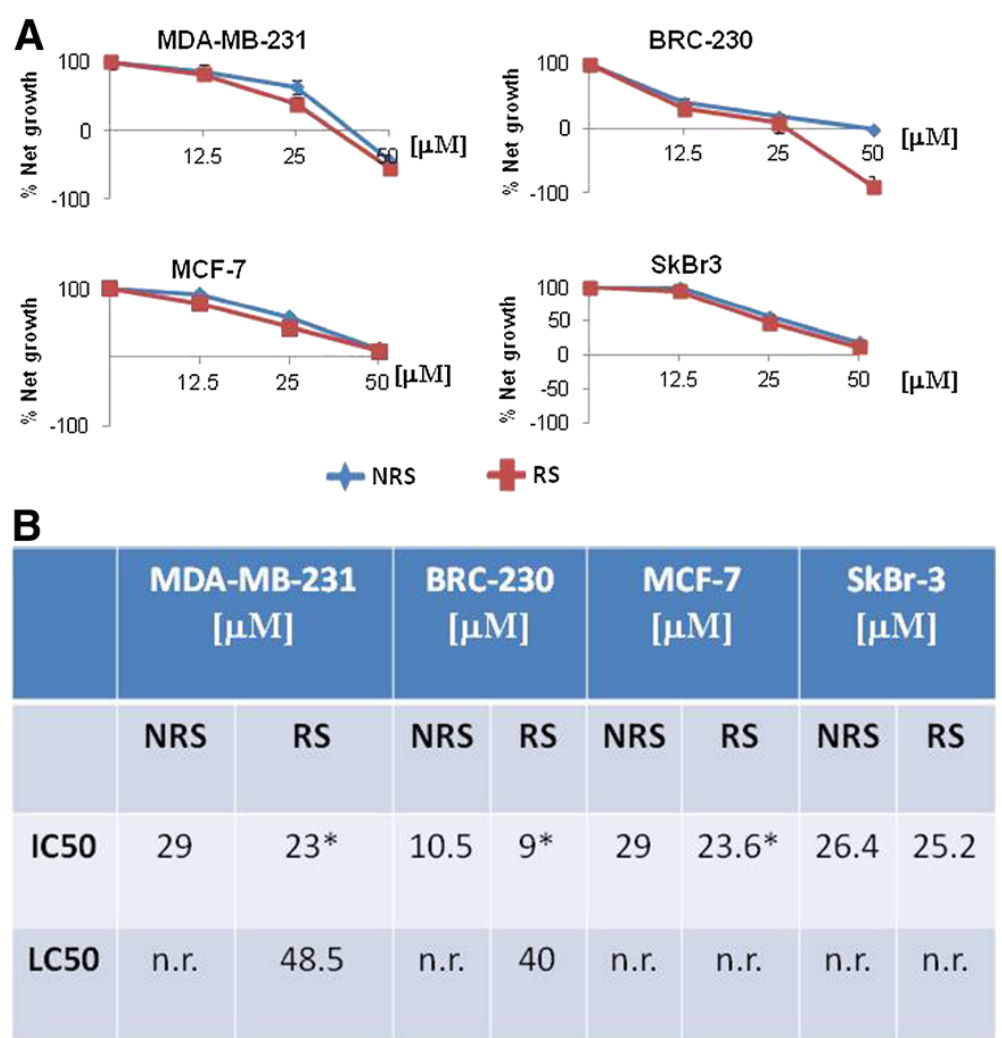

Figure 2 Comparison between the two drug schedules, repeated (RS) and non-repeated (NRS). Data represent the mean \pm standard deviation (SD) of three independent experiments. Error bars represent the mean \pm SD. A) Dose-effect curves of Zol in breast cancer cell lines. Standard deviation never exceeded 5\%. B) IC50 and LC50 values in the 2 treatment schedules. Asterisks refer to values that differ significantly $(p<0.05)$ with respect to control values. n.r., not reached.

all cell lines, this was chosen for all subsequent experiments.

\section{Effect of zoledronic acid on the mevalonate pathway and proliferation markers \\ Triple negative cell lines}

Both treatments induced a strong reduction in RAS expression in MDA-MB-231 and BRC-230 cells. There was no difference in MAPK levels after treatment in BRC230 cell lines, whereas a strong decrease was observed after both treatments in MDA-MB-231 cells. Furthermore, a strong reduction of (Figure 3) pMAPK was observed in BRC-230 and, only slightly, in MDA-MB231. Although both schedules inhibited the migration power of both cell lines, the reduction was more evident in BRC-230 (Figure 4). This result was confirmed by western blot analysis of RHO, which decreased after treatment.

We evaluated Ras activity in MDA-MB-231 and observed a $50 \%$ decrease in its activity in both schedules. Ras expression levels decreased by about tenfold in cells exposed to RS and by about twofold in NRS-treated cells compared to control (Figure 5). Expressing this result as the ratio Ras expression/Ras activity in cells exposed to RS, we observed a difference between treated and non treated cells. No difference was found in Rho activity before or after treatment (data not shown).

\section{MCF-7 and SkBr3 cell lines}

In these two cell lines, the decrease in RAS and pMAPK was lower compared to that observed in triple-negative cells, and was more evident in SKBr3 cells (Figure 3). MAPK levels showed no change after treatment in MCF-7 cell lines, while a slight increase in expression was observed after treatment with RS in SKBr3. Both treatment schedules did not modify the migration power of either cell line. This result was also confirmed by the absence of modulation of RHO expression by western blot (Figure 4).

The differences observed in the cytotoxicity data and in the modulation of the mevalonate pathways cannot be attributed to a different uptake of $\mathrm{Zol}$ of the cell lines. In fact, no difference was detected in the accumulation of unprenylated Rap1A, a surrogate marker of Zol uptake (Figure 5). 


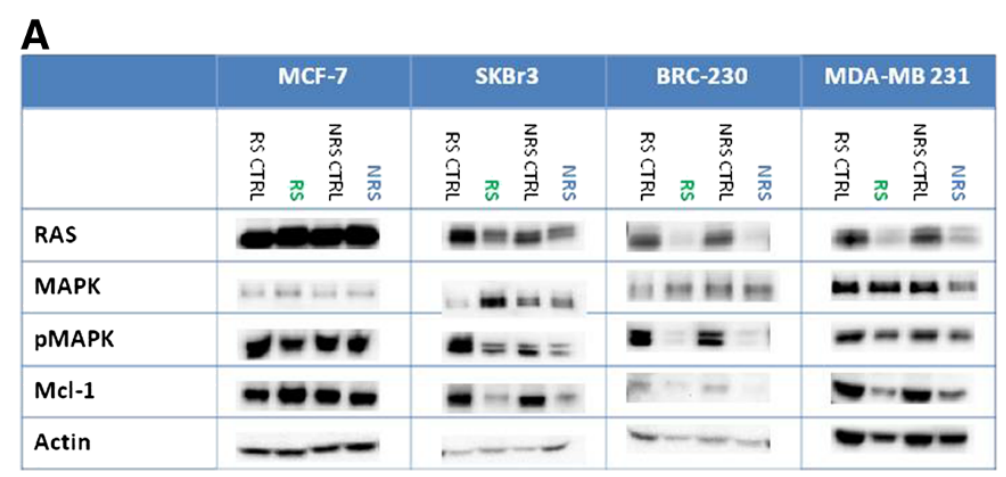

B

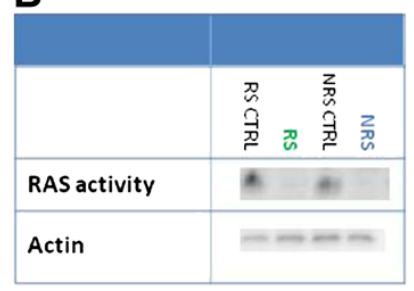

C

\begin{tabular}{|l|c|c|c|}
\hline \multirow{2}{*}{ MDA-MB-231 } & \multicolumn{3}{|c|}{ Band intensity } \\
\cline { 2 - 4 } & Ras expression & Ras activity & $\begin{array}{c}\text { Ras expression/ } \\
\text { activity }\end{array}$ \\
\hline Ctrl-RS & $1.35^{*} 10^{6}$ & $5.17^{*} 10^{5}$ & 2.61 \\
\hline RS & $1.42^{*} 10^{5}$ & $2.74^{*} 10^{5}$ & 0.52 \\
\hline Ctrl-NRS & $4.42^{*} 10^{5}$ & $4.5^{*} 10^{5}$ & 0.98 \\
\hline NRS & $2.46^{*} 10^{5}$ & $2.7^{*} 10^{5}$ & 0.91 \\
\hline
\end{tabular}

Figure 3 Effect of Zol on the mevalonate pathway and on proliferation markers. A) Western blot analyses. B) Ras activity evaluated by western blot. C) Band density quantifications by Quantity one software.

\section{Apoptosis}

\section{Triple negative cell lines}

Zol induced apoptosis in both the triple negative cell lines used as experimental models (Figure 6). Both treatment schedules induced a significant percentage of apoptotic cells compared to the untreated control. However, MDA-MB-231 showed a higher percentage of apoptotic cells following RS compared to NRS treatment,

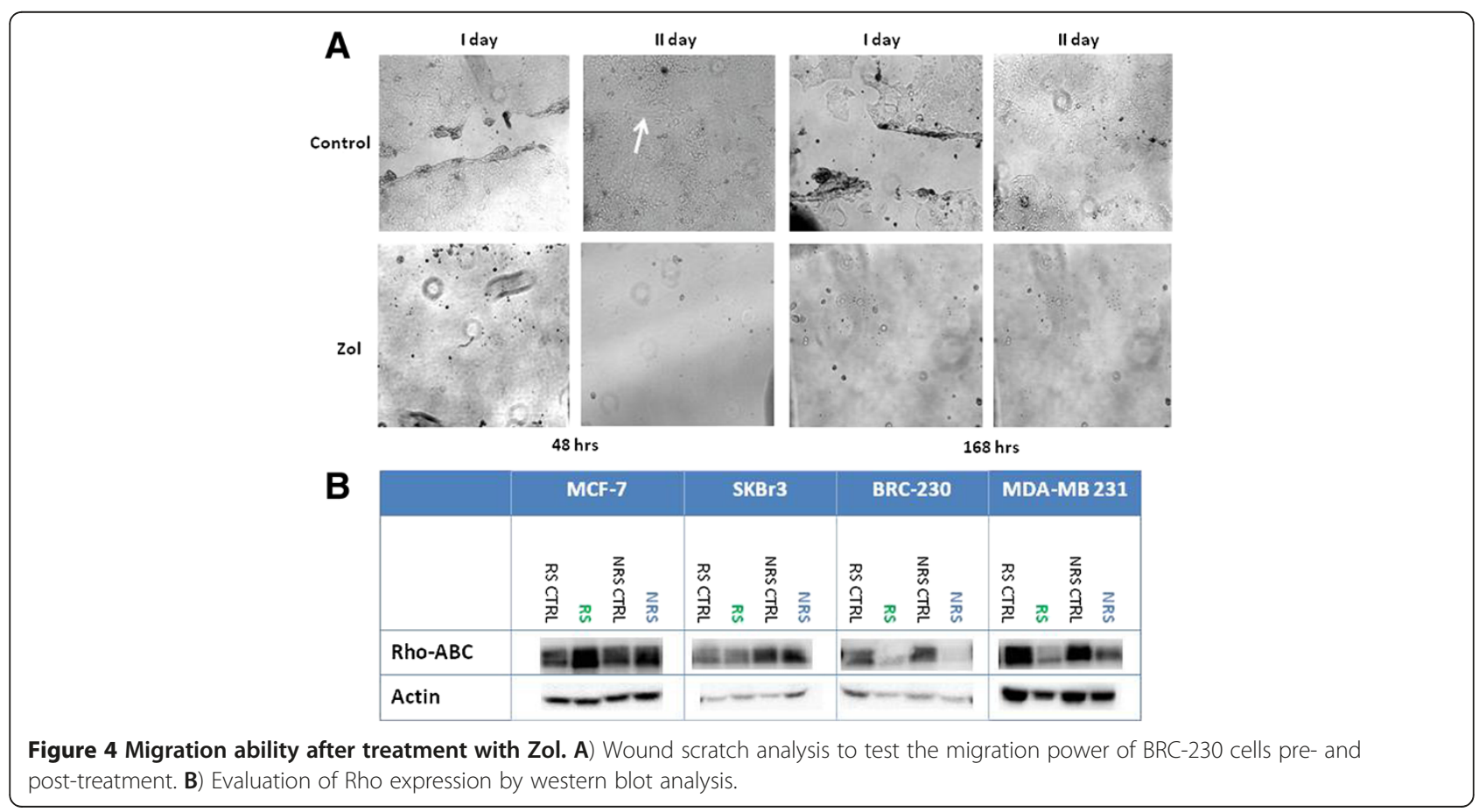




\begin{tabular}{|c|c|c|c|c|}
\hline & MCF-7 & SkBr3 & BRC-230 & MDA-MB 231 \\
\hline & 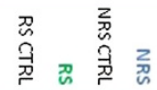 & 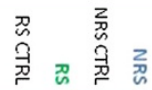 & 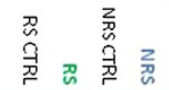 & 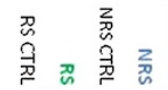 \\
\hline Rap 1a & $-\pi=0$ & $=-7=$ & $=1=$ & $=-1=$ \\
\hline Actin & $-\ldots$ & $-\infty-\infty$ & $\ldots$ & $-\cdots$ \\
\hline
\end{tabular}

Figure 5 Evaluation of Rap1a levels by western blot analysis.

without reaching statistical significance (44\% compared to $30.6 \%)$. Conversely, BRC-230, showed a higher percentage of apoptotic cells after NSR treatment (48\%) compared to RS (40\%), without reaching statistical significance. Apoptosis was confirmed by western blot by a decrease in the levels of pro-caspase 3, 8 and 9 in both cell lines, without detection of the active forms. In MDA-MB-231, the levels of $\mathrm{Bcl} 2$ expression decreased after both treatments, whereas in BRC-230 the protein was not appreciably expressed (Figure 6). Furthermore, a decrease of mcl-1 expression was detected in both cell lines.

\section{MCF-7 and SkBr3 cell lines}

No apoptosis was observed in MCF-7, even if we detected the presence of debris, indicating early cell death. An almost complete disappearance of $\mathrm{Bcl} 2$ expression was also observed in MCF7 cells treated with RS. In SKBr3, the percentage of apoptotic cells was higher in treated cells following both treatment schedules compared to untreated control (not significant) (Figure 6). In addition, a strong reduction of MCL-1 was observed only in the SKBr3 cell line for both treatments. However, NRS treatment induced a higher percentage of

\section{A}

\begin{tabular}{|c|c|c|c|c|}
\hline & MCF-7 & SKBr3 & BRC-230 & MDA-MB 231 \\
\hline & 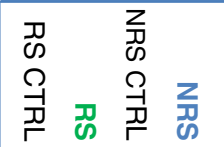 & 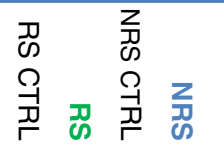 & 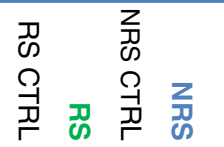 & 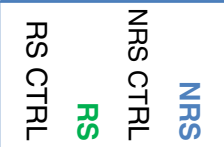 \\
\hline Pro-caspase 3 & $\pi$ & Dand & -1 & $=-\cdots$ \\
\hline Pro-caspase 8 & $-\infty-0$ & $=-\infty$ & -- & $0-\infty$ \\
\hline Pro-caspase 9 & $-\infty$ & - & $=--$ & ---- \\
\hline Actin & $\ldots-$ & $\ldots$ & $-\cdots$ & $0-\infty$ \\
\hline
\end{tabular}

B

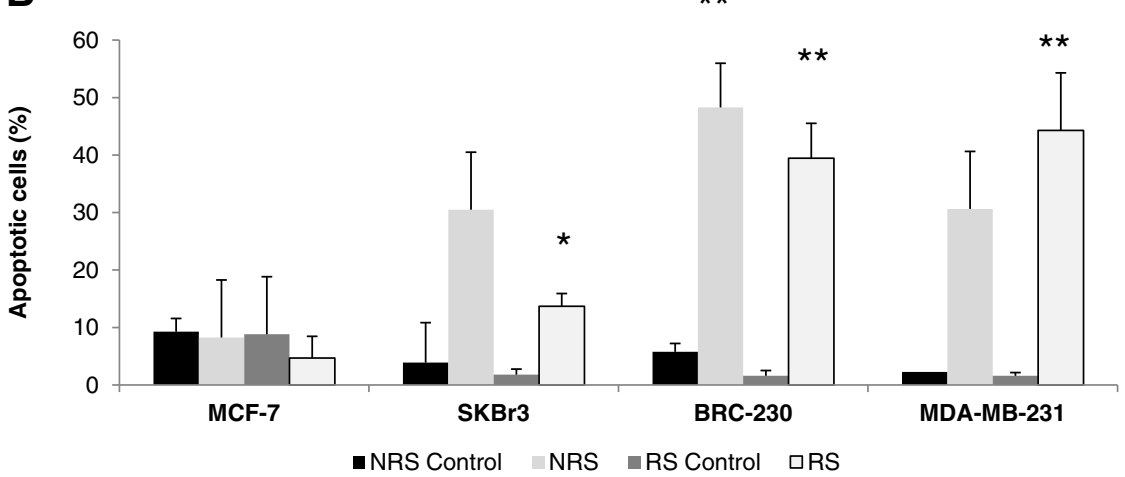

Figure 6 Apoptotic cells evaluated by TUNEL assay. Data represent the mean \pm SD of three independent experiments. Error bars represent the mean \pm SD. ${ }^{*} p<0.05,{ }^{* *} p<0.01$. A) Western blot data about modulation of apoptotic markers after the two treatment schedules in the 4 breast cancer cell lines. B) Percentage of cells in apoptosis. Data represent the mean \pm SD of three independent experiments. ${ }^{*} p<0.05,{ }^{* *} p<0.01$. 
apoptotic cells (31\%) in this cell line compared to the RS treatment (14\%).

\section{Cell cycle analysis}

\section{Triple negative cell lines}

Both treatment schedules induced a significant increase of the percentage of cells in G0/G1 in all cell lines used (Figure 7) compared to untreated controls. The percentage of cells that accumulated in G0/G1 was $45.5 \%$ higher after RS with respect to control compared to NRS treatment (16.9\%) in the BRC-230 cell line. This accumulation was also confirmed by the increase in p21 expression in RS in MDA-MB-231cells, whereas in BRC-230, the protein was not appreciably expressed. p27 expression was not evaluable in either of the two lines.

\section{MCF-7 and SKBr3 cell lines}

In $\mathrm{SKBr} 3$ cells, RS treatment induced an accumulation of cells in G0/G1 resulting in an increase of about 9\% compared to untreated cells $(p=0.005)$. Instead, NRS induced a cell accumulation in the $S$ phase with a $50 \%$ increase in blocked cells compared to controls $(p=0.01)$. Cell cycle perturbation was confirmed by an increase in p27 in both cell lines after Zol treatment.

The pulse-chase experiment was performed on MDAMB-231 exposed to RS. After 72 hrs and $168 \mathrm{hrs}$ all untreated cells were BrdU-positive, indicating that every cell had entered S phase at least once and that there was a regular cell proliferation. Conversely, after the same times treated cells showed a fraction of BrdU-negative cells, confirming that Zol had arrested a certain percentage of cells in G0/1 phase. Of note, very few treated cells (BrdU-positive or -negative) entered or left $\mathrm{S}$ phase after $72 \mathrm{hrs}$, as also shown by the absence of clearly visible $\mathrm{S}$ and $\mathrm{G} 2 / \mathrm{M}$ phases on the propidium iodide fluorescence axis (Figure 8). Forty-eight hrs after the end of treatment almost all cells were dead or in late-stage apoptosis and could thus no longer usable for $\mathrm{S}$ phase evaluation (data not shown).
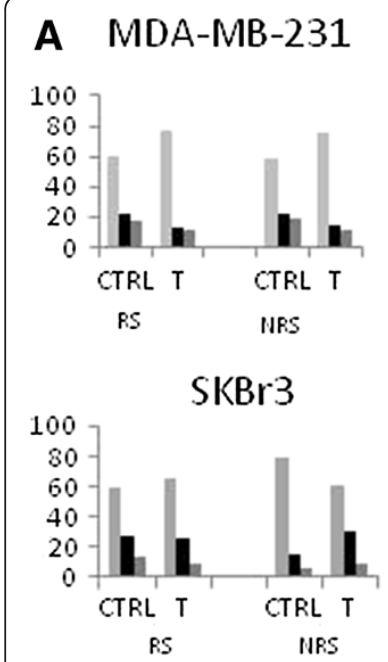
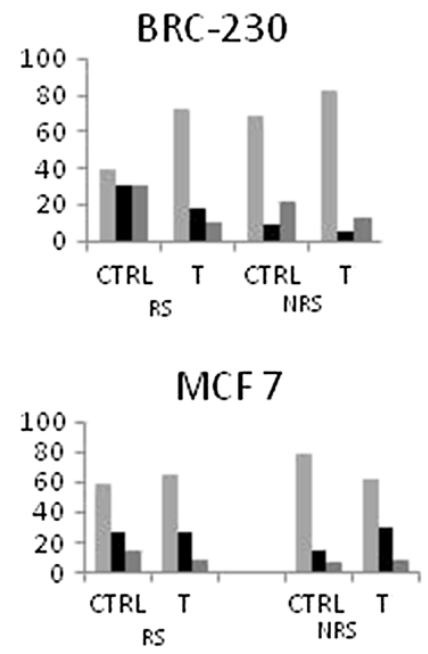

B

\begin{tabular}{|l|cccc|}
\hline Cell Line & Treatment & $\% \mathrm{G} 0 / \mathrm{G1}$ & $\% \mathrm{~S}$ & $\% \mathrm{G} 2 / \mathrm{M}$ \\
\hline \multirow{2}{*}{ BRC-230 } & RS & $\mathbf{0 . 0 0 1 4 2 6}$ & $\mathbf{0 . 0 0 0 7 8 3}$ & $\mathbf{0 . 0 0 2 3 8 1}$ \\
& NRS & $7.24 \mathrm{E}-05$ & $\mathbf{0 . 0 0 0 9 0 1}$ & $2.07 \mathrm{E}-05$ \\
MDA-MB-231 & RS & $\mathbf{0 . 0 0 5 8 1 3}$ & 0.268803 & $\mathbf{0 . 0 0 4 3 3 5}$ \\
& NRS & $\mathbf{0 . 0 0 6 1 1 7}$ & $\mathbf{0 . 0 1 3 8 0 6}$ & 0.119624 \\
SKBr3 & RS & $\mathbf{0 . 0 2 4 2 1 1}$ & $\mathbf{0 . 0 0 6 6 9 9}$ & 0.05895 \\
& NRS & $\mathbf{0 . 0 0 6 1 1 7}$ & $\mathbf{0 . 0 1 3 8 0 6}$ & 0119624 \\
MCF 7 & RS & $\mathbf{0 . 0 0 0 4 0}$ & $\mathbf{0 . 0 0 3 4 3}$ & $\mathbf{0 . 0 0 0 6 5}$ \\
& NRS & $\mathbf{0 . 0 0 0 2 1}$ & $\mathbf{0 . 0 0 1 8 5 6}$ & $3.9 \mathrm{E}-05$ \\
\hline
\end{tabular}

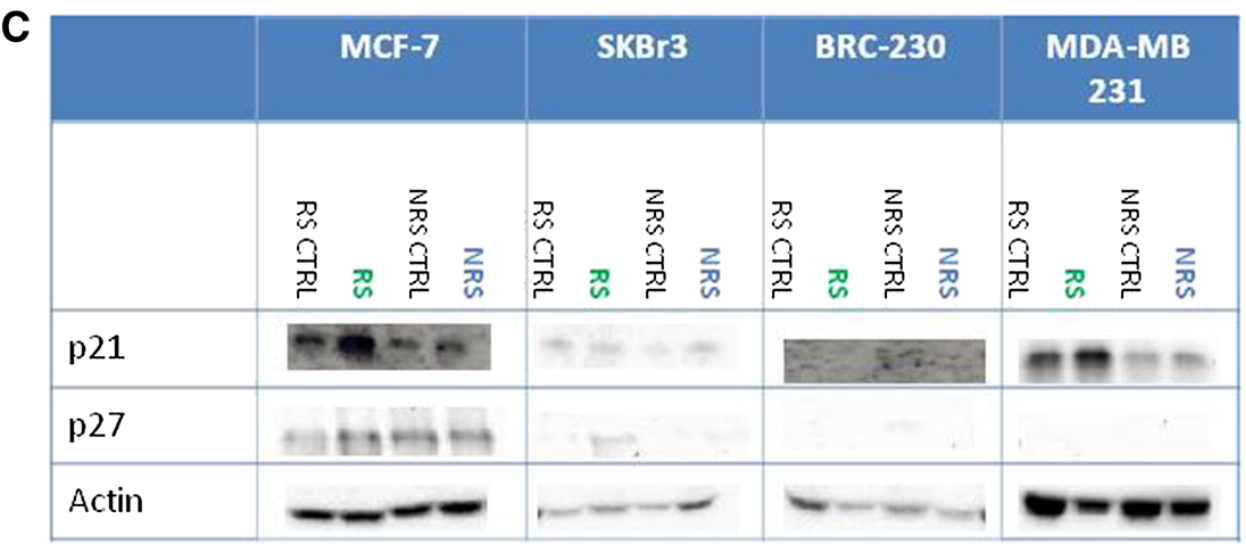

Figure 7 Effect of Zol on the cell cycle. A) Distribution of cells in the different cell cycle phases pre- and post-treatment. B) All $p$ values were $<0.01$ with the exception of $S$ phase of BRC-230 cells exposed to NRS, G2/M phase of MDA-MB-231 cells exposed to NRS and G2/M of SkBr3 cells exposed to both treatments. C) Expression of p21 and p27 pre- and post-treatment in the different cell lines. 


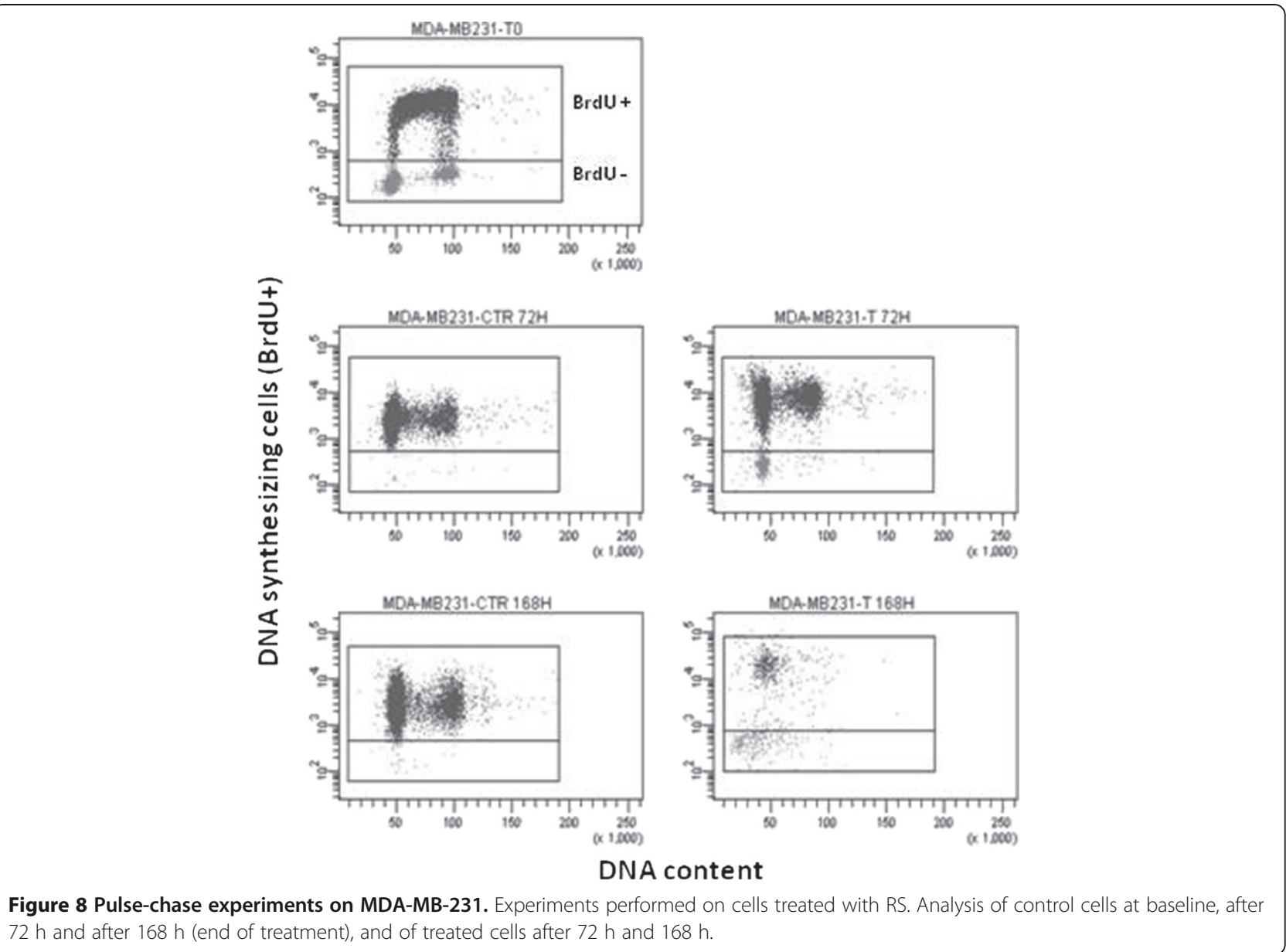

\section{Discussion}

In the present study, Zol induced cytostatic and cytocidal effects on breast cancer cell lines, in agreement with results from previous papers $[38,39]$. To mimic the bone microenvironment, concentrations of Zol used in our experiments $(12.5,25,50 \mu \mathrm{M})$ were higher than the transient circulatory levels detected in patients. However, the concentrations used were in agreement with previously reported in vitro and in vivo data [15,40-43]. Moreover, it is well known that the pharmacokinetics and pharmakodinamic properties of Zol result in a rapid drug elimination by renal excretion and rapid uptake and accumulation within bone [44,45]. This accumulation has also been supported by a xenograft study which showed a high bisphosphonate concentration in bone compared to plasma [46]. For the reasons described above, we decided to use a higher concentration compared to that utilized in the clinical setting.

As expected, Zol exerted dose-dependent effects on cell proliferation in all cell lines following both treatment exposures. However, the repeated treatment induced a statistically significant modulation of cell proliferation and cytotoxic effect only in triple negative breast cancer cell lines. These data support results obtained in a preclinical model of bone metastasis induced in a triple negative cell line, showing that the antitumor effect of bisphosphonates increases when the drug is administered at low dose with a daily or weekly schedule [21], inducing a reduction of osteolyisis and growth of tumor in the bone.

Our results also confirm recent findings on the increased delivery of Zol to cancer cells both in vitro and in vivo through the use of liposomes or nanoparticles. It is hypothesized that the delivery of Zol by 'stealth' nanovectors mimics repeated administrations of Zol, and this would seem to be confirmed by the increased in vitro activity of the nanodevices encapsulating Zol [47-49].

Zol is known to block enzymes of the mevalonate pathway such as farnesyl pyrophosphate synthase, and/ or geranylgeranyl pyrophosphate synthase [50]. This block causes a deficiency in isoprenoids which are essential for the post-translation lipid modification of signalling GTPases such as RHO and RAS [10,51,52]. To our knowledge, ours is the first Zol study on triple-negative lines to observe a modulation of RAS and RHO 
pathways; indeed, the decrease in RAS and pMAPK expression could explain the observed inhibition of cell proliferation. We also observed a decrease in RAS activity after treatment.

The wound scratch test showed a decrease of the migration power of triple-negative treated cells, most probably due to a decrease in RHO expression. The induction of the caspase pathway by Zol supports the hypothesis that apoptosis is linked to these pathways in triple-negative cell lines. Conversely, in HER2 overespressing (SKBr3) and positive hormone receptor cells (MCF-7), Zol induced only a cytostatic effect. In fact, a block (inhibition) of the RAS pathway was observed, with a reduction of pMAPK expression in SKBr3 cells, confirming the action of Zol to inhibit the mevalonate pathway.

There are conflicting literature data on breast cancer sensitivity to Zol, possibly due to the different HER2 and hormone receptors' patterns of breast cancers. A study reported that MCF-7 and MDA-MB-231 cell lines were similarly sensitive to bisphosphonates [53]. Conversely, another study reported that clodronate reduced cell survival of MDA-MB-231, but not MCF-7 cells [54]. Hu et al. have characterized genetic alterations and oncogenic pathway in different breast cancers subtypes, both in tissue and in cell lines, and found that all mutations in BRAF, KRAS and HRAS were significantly associated with the triple negative subtype [55]. We hypothesized that triple-negative cell lines are more sensitive to Zol because the mevalonate pathway is blocked and the KRAS pathway is constitutively active. This hypothesis fits in with the MDA-MB-231 cell line profile, which harbors mutated KRAS and BRAF, while BRC-230 did not present any BRAF, KRAS and HRAS alterations (data not shown). However, BRC-230, presented a genetic amplification of EGFR and concomitant overexpression of the protein as observed in triple-negative breast cancers [56]. The hormone receptor (MCF-7) and HER2positive $(\mathrm{SKBr} 3)$ cell lines, not presenting any alterations in BRAF, KRAS, NRAS, HRAS or EGFR, appear to be less sensitive to both Zol schedules. A possible explanation could be the lack of caspase 3 in MCF-7 [41] and the overexpression of HER2 in SKBr3, which are involved in overcoming inhibition of the RAS pathway.

\section{Conclusions}

Our work confirms the direct antitumor activity of Zol in human cell lines, as previously reported in in vitro and mouse models [21,22] and recently observed in patients in the Azure trial [57]. Furthermore, we highlighted an increase in the efficacy of Zol with repeated doses. In addition, the two triple-negative breast cancer cell lines were more sensitive to Zol than the other cell lines. These results indicate that it would be interesting to carry out further trials on animal models and, after successful completion, on patients. Finally, we performed an in-depth study of the mechanisms of action of Zol, observing that the KRAS/BRAF pathways are probably responsible for the sensitivity of the triple negative cell line. These data provide a sound rationale for using biologically targeted drugs for KRAS/BRAF/ EGFR inhibition in combination with Zol. PARP inhibitors are another drug group that could potentially be used with Zol. Such hypotheses obviously need to be confirmed but are interesting in view of the limited treatment options available for patients with triplenegative breast cancer.

\section{Competing interests}

The authors declare that they have no conflict of interests.

\section{Authors' contributions}

TI, LM and DA conceived the study and, together with AT and FF, participated in its design. LM and MZ performed part of the experimental work. ES carried out the chemosensitivity tests, CL the western blot analyses, SC cell cycle and apoptosis analyses, and PU the molecular genetic studies. TI, LM, AT and ES contributed to manuscript drafting. WZ and DA critically revised the manuscript for intellectual content. All authors approved the final version of the manuscript.

\section{Acknowledgements}

The authors thank Ursula Elbling for editing the manuscript.

\section{Author details}

'Osteoncology Center, IRCCS Istituto Scientifico Romagnolo per lo Studio e la Cura dei Tumori (IRST), via P. Maroncelli 40, 47014, Meldola, FC, Italy.

${ }^{2}$ Biosciences Laboratory, IRCCS Istituto Scientifico Romagnolo per lo Studio e la Cura dei Tumori (IRST), via P. Maroncelli 40, 47014, Meldola, FC, Italy.

Received: 26 July 2012 Accepted: 14 November 2012

Published: 22 November 2012

\section{References}

1. Jemal A, Siegel R, Ward E, Murray T, Xu J, Thun MJ: Cancer statistics, 2007. CA Cancer J Clin 2007, 57(1):43-66.

2. Coleman RE: Clinical features of metastatic bone disease and risk of skeletal morbidity. Clin Cancer Res 2006, 12 (20 Pt 2):6243s-6249s.

3. Mercatali L, Ibrahim T, Sacanna E, Flamini E, Scarpi E, Calistri D, Ricci M, Serra P, Ricci R, Zoli W, Kang Y, Amadori D: Bone metastases detection by circulating biomarkers: OPG and RANK-L. Int J Oncol 2011, 39(1):255-261.

4. Sacanna E, Ibrahim T, Gaudio M, Mercatali L, Scarpi E, Zoli W, Serra P, Bravaccini S, Ricci R, Serra L, Amadori D: The role of CXCR4 in the prediction of bone metastases from breast cancer: a pilot study. Oncology 2011, 80(3-4):225-231.

5. Martin TJ, Moseley JM: Mechanisms in the skeletal complications of breast cancer. Endocr Relat Cancer 2000, 7(4):271-284.

6. Ibrahim T, Flamini E, Fabbri L, Serra P, Mercatali L, Ricci R, Sacanna E, Falasconi MC, Casadei R, Galassi R, Giannini M, Bazzocchi O, Calzolari F, Nunziatini R, Gaudio M, Maltoni M, Amadori D: Multidisciplinary approach to the treatment of bone metastases: Osteo-Oncology Center, a new organizational model. Tumori 2009, 95(3):291-297.

7. Coleman RE: Metastatic bone disease: clinical features, pathophysiology and treatment strategies. Cancer Treat Rev 2001, 27(3):165-176.

8. Mountzios G, Dimopoulos MA, Bamias A, Papadopoulos G, Kastritis E, Syrigos K, Pavlakis G, Terpos E: Abnormal bone remodeling process is due to an imbalance in the receptor activator of nuclear factor-kappaB ligand (RANKL)/osteoprotegerin (OPG) axis in patients with solid tumors metastatic to the skeleton. Acta Oncol 2007, 46(2):221-229.

9. Ibrahim T, Flamini E, Mercatali L, Sacanna E, Serra P, Amadori D: Pathogenesis of osteoblastic bone metastases from prostate cancer. Cancer 2010, 116(6):1406-1418. 
10. Rogers MJ, Gordon S, Benford HL, Coxon FP, Luckman SP, Monkkonen J, Frith JC: Cellular and molecular mechanisms of action of bisphosphonates. Cancer 2000, 88(12 Suppl):2961-2978.

11. Lipton A, Cook R, Saad F, Major P, Garnero P, Terpos E, Brown JE, Coleman RE: Normalization of bone markers is associated with improved survival in patients with bone metastases from solid tumors and elevated bone resorption receiving zoledronic acid. Cancer 2008, 113(1):193-201.

12. Doggrell SA: Clinical efficacy and safety of zoledronic acid in prostate and breast cancer. Expert Rev Anticancer Ther 2009, 9(9):1211-1218.

13. Costa L, Lipton A, Coleman RE: Role of bisphosphonates for the management of skeletal complications and bone pain from skeletal metastases. Support Cancer Ther 2006, 3(3):143-153.

14. Santini D, Virzi V, Fratto ME, Bertoldo F, Sabbatini R, Berardi R, Calipari N, Ottaviani D, Ibrahim T: Can we consider zoledronic acid a new antitumo agent? Recent evidence in clinical setting. Curr Cancer Drug Targets 2010, 10(1):46-54

15. Guise TA: Antitumor effects of bisphosphonates: promising preclinical evidence. Cancer Treat Rev 2008, 34(Suppl 1):S19-S24.

16. Jagdev SP, Coleman RE, Shipman CM, Rostami HA, Croucher PI: The bisphosphonate, zoledronic acid, induces apoptosis of breast cancer cells: evidence for synergy with paclitaxel. Br J Cancer 2001, 84(8):1126-1134

17. van der Pluijm $G$, Vloedgraven $H$, van Beek $E$, van der Wee-Pals L, Lowik C, Papapoulos S: Bisphosphonates inhibit the adhesion of breast cancer cells to bone matrices in vitro. J Clin Invest 1996, 98(3):698-705.

18. Boissier S, Ferreras M, Peyruchaud O, Magnetto S, Ebetino FH, Colombel M, Delmas P, Delaisse JM, Clezardin P: Bisphosphonates inhibit breast and prostate carcinoma cell invasion, an early event in the formation of bone metastases. Cancer Res 2000, 60(11):2949-2954.

19. Wood J, Bonjean K, Ruetz S, Bellahcene A, Devy L, Foidart JM, Castronovo V, Green JR: Novel antiangiogenic effects of the bisphosphonate compound zoledronic acid. J Pharmacol Exp Ther 2002, 302(3):1055-1061.

20. Santini D, Vincenzi B, Dicuonzo G, Avvisati G, Massacesi C, Battistoni F, Gavasci M, Rocci L, Tirindelli MC, Altomare V, Tocchini M, Bonsignori M, Tonini G: Zoledronic acid induces significant and long-lasting modifications of circulating angiogenic factors in cancer patients. Clin Cancer Res 2003, 9(8):2893-2897.

21. Daubine F, Le Gall C, Gasser J, Green J, Clezardin P: Antitumor effects of clinical dosing regimens of bisphosphonates in experimental breast cancer bone metastasis. J Natl Cancer Inst 2007, 99(4):322-330.

22. Ottewell PD, Deux B, Monkkonen H, Cross S, Coleman RE, Clezardin P, Holen I: Differential effect of doxorubicin and zoledronic acid on intraosseous versus extraosseous breast tumor growth in vivo. Clin Cancer Res 2008, 14(14):4658-4666.

23. Gnant M, Mlineritsch $B$, Schippinger $W$, Luschin-Ebengreuth $G$, Postlberger S, Menzel C, Jakesz R, Seifert M, Hubalek M, Bjelic-Radisic V, Samonigg H, Tausch C, Eidtmann H, Steger G, Kwasny W, Dubsky P, Fridrik M, Fitzal F, Stierer M, Rucklinger E, Greil R, Marth C: Endocrine therapy plus zoledronic acid in premenopausal breast cancer. N Engl J Med 2009, 360(7):679-691.

24. Coleman RE, Lipton A, Roodman GD, Guise TA, Boyce BF, Brufsky AM, Clezardin P, Croucher PI, Gralow JR, Hadji P, Holen I, Mundy GR, Smith MR, Suva LJ: Metastasis and bone loss: advancing treatment and prevention. Cancer Treat Rev 2010, 36(8):615-620.

25. Marra M, Abbruzzese A, Addeo R, Del Prete S, Tassone P, Tonini G, Tagliaferri P, Santini D, Caraglia M: Cutting the limits of aminobisphosphonates: new strategies for the potentiation of their anti-tumour effects. Curr Cancer Drug Targets 2009, 9(7):791-800.

26. Caraglia M, Marra M, Naviglio S, Botti G, Addeo R, Abbruzzese A: Zoledronic acid: an unending tale for an antiresorptive agent. Expert Opin Pharmacother 2010, 11(1):141-154.

27. Black DM, Delmas PD, Eastell R, Reid IR, Boonen S, Cauley JA, Cosman F, Lakatos P, Leung PC, Man Z, Mautalen C, Mesenbrink P, Hu H, Caminis J, Tong K, Rosario-Jansen T, Krasnow J, Hue TF, Sellmeyer D, Eriksen EF, Cummings SR: Once-yearly zoledronic acid for treatment of postmenopausal osteoporosis. N Engl J Med 2007, 356(18):1809-1822.

28. Hershman DL, McMahon DJ, Crew KD, Cremers S, Irani D, Cucchiara G, Brafman L, Shane E: Zoledronic acid prevents bone loss in premenopausal women undergoing adjuvant chemotherapy for early-stage breast cancer. J Clin Oncol 2008, 26(29):4739-4745.
29. Santini D, Galluzzo S, Vincenzi B, Schiavon G, Fratto E, Pantano F, Tonini G: New developments of aminobisphosphonates: the double face of Janus. Ann Oncol 2007, 18(Suppl 6):vi164-vi167.

30. Zhao X, Xu X, Guo L, Ragaz J, Guo H, Wu J, Shao Z, Zhu J, Guo X, Chen J, Zhu B, Wang Z, Hu X: Biomarker alterations with metronomic use of low-dose zoledronic acid for breast cancer patients with bone metastases and potential clinical significance. Breast Cancer Res Treat 2010, 124(3):733-743.

31. Amadori D, Bertoni L, Flamigni A, Savini S, De Giovanni C, Casanova S, De Paola F, Amadori A, Giulotto E, Zoli W: Establishment and characterization of a new cell line from primary human breast carcinoma. Breast Cancer Res Treat 1993, 28(3):251-260.

32. Skehan P, Storeng R, Scudiero D, Monks A, McMahon J, Vistica D, Warren JT, Bokesch H, Kenney S, Boyd MR: New colorimetric cytotoxicity assay for anticancer-drug screening. J Natl Cancer Inst 1990, 82(13):1107-1112.

33. Caraglia M, Leardi A, Corradino S, Ciardiello F, Budillon A, Guarrasi R, Bianco $A R$, Tagliaferri P: Alpha-interferon potentiates epidermal growth factor receptor-mediated effects on human epidermoid carcinoma KB cells. Int J Cancer 1995, 61(3):342-347.

34. Monks A, Scudiero D, Skehan P, Shoemaker R, Paull K, Vistica D, Hose C, Langley J, Cronise $P$, Vaigro-Wolff A, et al: Feasibility of a high-flux anticancer drug screen using a diverse panel of cultured human tumor cell lines. J Natl Cancer Inst 1991, 83(11):757-766.

35. Hahnel A, Wichmann H, Kappler M, Kotzsch M, Vordermark D, Taubert H, Bache M: Effects of osteopontin inhibition on radiosensitivity of MDAMB-231 breast cancer cells. Radiat Oncol 2010, 5:82.

36. Lamberti A, Longo O, Marra M, Tagliaferri P, Bismuto E, Fiengo A, Viscomi C, Budillon A, Rapp UR, Wang E, Venuta S, Abbruzzese A, Arcari P, Caraglia M: C-Raf antagonizes apoptosis induced by IFN-alpha in human lung cancer cells by phosphorylation and increase of the intracellular content of elongation factor 1A. Cell Death Differ 2007 14(5):952-962

37. Marra M, Santini D, Meo G, Vincenzi B, Zappavigna S, Baldi A, Rosolowski M, Tonini G, Loeffler M, Lupu R, Addeo SR, Abbruzzese A, Budillon A, Caraglia M: Cyr61 downmodulation potentiates the anticancer effects of zoledronic acid in androgen-independent prostate cancer cells. Int J Cancer 2009, 125(9):2004-2013.

38. Osborne A: Zoledronic acid. Clin J Oncol Nurs 2002, 6(6):365-366.

39. Hatoum HT, Lin SJ, Smith MR, Barghout V, Lipton A: Zoledronic acid and skeletal complications in patients with solid tumors and bone metastases: analysis of a national medical claims database. Cancer 2008 113(6):1438-1445.

40. Senaratne SG, Mansi JL, Colston KW: The bisphosphonate zoledronic acid impairs Ras membrane [correction of impairs membrane] localisation and induces cytochrome c release in breast cancer cells. Br J Cancer 2002, 86(9):1479-1486.

41. Rachner TD, Singh SK, Schoppet M, Benad P, Bornhauser M, Ellenrieder V, Ebert R, Jakob F, Hofbauer LC: Zoledronic acid induces apoptosis and changes the TRAIL/OPG ratio in breast cancer cells. Cancer Lett 2010, 287(1):109-116.

42. Green JR: Bisphosphonates: preclinical review. Oncologist 2004, 9(Suppl 4):3-13.

43. Fabbri F, Brigliadori G, Carloni S, Ulivi P, Vannini I, Tesei A, Silvestrini R, Amadori D, Zoli W: Zoledronic acid increases docetaxel cytotoxicity through pMEK and $\mathrm{Mcl}-1$ inhibition in a hormone-sensitive prostate carcinoma cell line. J Transl Med 2008, 6:43.

44. Chen T, Berenson J, Vescio R, Swift R, Gilchick A, Goodin S, LoRusso P, Ma P, Ravera C, Deckert F, Schran H, Seaman J, Skerjanec A: Pharmacokinetics and pharmacodynamics of zoledronic acid in cancer patients with bone metastases. J Clin Pharmacol 2002, 42(11):1228-1236.

45. Caraglia M, Santini D, Marra M, Vincenzi B, Tonini G, Budillon A: Emerging anti-cancer molecular mechanisms of aminobisphosphonates. Endocr Relat Cancer 2006, 13(1):7-26.

46. Sato M, Grasser W, Endo N, Akins R, Simmons H, Thompson DD, Golub E, Rodan GA: Bisphosphonate action, Alendronate localization in rat bone and effects on osteoclast ultrastructure. J Clin Invest 1991, 88(6):2095-2105.

47. Salzano G, Marra M, Porru M, Zappavigna S, Abbruzzese A, La Rotonda MI, Leonetti C, Caraglia M, De Rosa G: Self-assembly nanoparticles for the delivery of bisphosphonates into tumors. Int J Pharm 2011, 403(1-2):292-297. 
48. Marra M, Salzano G, Leonetti C, Porru M, Franco R, Zappavigna S, Liguori G, Botti G, Chieffi P, Lamberti M, Vitale G, Abbruzzese A, La Rotonda MI, De Rosa G, Caraglia M: New self-assembly nanoparticles and stealth liposomes for the delivery of zoledronic acid: a comparative study. Biotechnol Adv 2012, 30(1):302-309.

49. Marra M, Salzano G, Leonetti C, Tassone P, Scarsella M, Zappavigna S, Calimeri T, Franco R, Liguori G, Cigliana G, Ascani R, La Rotonda MI, Abbruzzese A, Tagliaferri P, Caraglia M, De Rosa G: Nanotechnologies to use bisphosphonates as potent anticancer agents: the effects of zoledronic acid encapsulated into liposomes. Nanomedicine 2011, 7(6):955-964.

50. Amin D, Cornell SA, Gustafson SK, Needle SJ, Ullrich JW, Bilder GE, Perrone MH: Bisphosphonates used for the treatment of bone disorders inhibit squalene synthase and cholesterol biosynthesis. J Lipid Res 1992, 33(11):1657-1663.

51. van Beek E, Pieterman E, Cohen L, Lowik C, Papapoulos S: Farnesyl pyrophosphate synthase is the molecular target of nitrogen-containing bisphosphonates. Biochem Biophys Res Commun 1999, 264(1):108-111.

52. Coxon FP, Helfrich MH, Van't Hof R, Sebti S, Ralston SH, Hamilton A, Rogers $\mathrm{MJ}$ : Protein geranylgeranylation is required for osteoclast formation, function, and survival: inhibition by bisphosphonates and GGTI-298. J Bone Miner Res 2000, 15(8):1467-1476.

53. Senaratne SG, Pirianov G, Mansi JL, Arnett TR, Colston KW: Bisphosphonates induce apoptosis in human breast cancer cell lines. Br J Cancer 2000, 82(8):1459-1468.

54. Busch M, Rave-Frank M, Hille A, Duhmke E: Influence of clodronate on breast cancer cells in vitro. Eur J Med Res 1998, 3(9):427-431.

55. Hu X, Stern HM, Ge L, O'Brien C, Haydu L, Honchell CD, Haverty PM, Peters BA, Wu TD, Amler LC, Chant J, Stokoe D, Lackner MR, Cavet G: Genetic alterations and oncogenic pathways associated with breast cancer subtypes. Mol Cancer Res 2009, 7(4):511-522.

56. Kobayashi S: Basal-like subtype of breast cancer: a review of its unique characteristics and their clinical significance. Breast Cancer 2008, 15(2):153-158

57. Coleman RE, Winter MC, Cameron D, Bell R, Dodwell D, Keane MM, Gil M, Ritchie D, Passos-Coelho JL, Wheatley D, Burkinshaw R, Marshall SJ, Thorpe $\mathrm{H}$ : The effects of adding zoledronic acid to neoadjuvant chemotherapy on tumour response: exploratory evidence for direct anti-tumour activity in breast cancer. Br J Cancer 2010, 102(7):1099-1105.

doi:10.1186/1475-2867-12-48

Cite this article as: Ibrahim et al:: Inhibition of breast cancer cell proliferation in repeated and non-repeated treatment with zoledronic acid. Cancer Cell International 2012 12:48.

\section{Submit your next manuscript to BioMed Central and take full advantage of:}

- Convenient online submission

- Thorough peer review

- No space constraints or color figure charges

- Immediate publication on acceptance

- Inclusion in PubMed, CAS, Scopus and Google Scholar

- Research which is freely available for redistribution 